\title{
Trading Room Educational Programs: Issues And Recommendations
}

Amit Sinha, (Email: mfsinha@isugw.indstate.edu), Indiana State University Eurico J. Ferreira, (Email: mfpref@isugw.indstate.edu), Indiana State University Ronald Green, (Email: bssgreen@isugw.indstate.edu), Indiana State University

\begin{abstract}
The last few decades have witnessed the transformation of financial markets in the United States. Electronic trading markets have now surpassed floor-based trading systems in terms of both trading volume and importance. The growth in technology-driven markets has led universities to evaluate and establish financial trading rooms in their College or School of Business. In this paper we discuss the purpose of such a room, the need for one, and how such a room fits into the overall mission of 'excellence in teaching' of a general College or School of Business. We find that the two most important factors to consider for a successful trading room program are faculty and curriculum.
\end{abstract}

\section{INTRODUCTION}

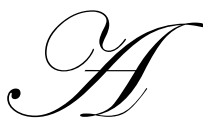

lthough a number of financial markets, including the New York Stock Exchange (the NYSE), have resisted the adoption of automated trading systems, the trend in favor of automated financial trading systems is unmistakable. The advent of technology has made financial markets even more complex and fast paced. Decisions have to be made on a real time basis and special training is required. ${ }^{1}$

Recognizing this trend and the need for experts who can trade on automated financial systems, a number of universities have implemented programs which provide students with valuable real life experiences in an academic setting. A partial list of such universities is provided in Table 1.

With displays and real time access to financial data, trading room facilities add a certain glitz to the ambience of a business program, hence the increasing desire of universities to have such facilities on their campuses. Such facilities often bring about curriculum changes and increase the reputation of the business program. ${ }^{2}$ The use of a trading room in an academic environment is also consistent with Experiential Learning (Kolbe, (1984)) principles such as: (1) people learn best from their own experiences and their own reviews, and (2) it is not enough to explain to people what to do, they must be shown how to actually do it and be encouraged to improve.

Trading room facilities require sizeable investment both monetary and non-monetary. Preliminary estimations indicate that the initial set-up costs for a trading room at our university would be approximately eight hundred thousand dollars, followed by an on-going annual expenditure of approximately fifty-four thousand dollars. The inflow from student tuition may, however, more than cover the annual recurring charges and justify the initial investment made.

The remainder of this paper is divided into four sections. Section 1 provides the purpose and need of a trading room at a general university. Section 2 discusses a typical trading room. Section 3 discusses two critical factors for success - curriculum and personnel. Section 4 concludes the paper and provides a summary of the benefits and concerns of having a trading room.

\footnotetext{
${ }^{1}$ Over fifty percent of the contracts presently traded in the Chicago Mercantile Exchange (the CME) are done electronically.

${ }^{2}$ It is expected that enhanced reputation, up to date curriculum, and the improved ambience will lead to improved enrollment and a better relationship with alumni. These are just a few benefits of having such facilities.
} 
Table 1: List Of Universities With Trading Room In Operation

\begin{tabular}{|c|c|c|}
\hline Name Of University & Trading Room Emphasis & Tuition \\
\hline MIT & $\begin{array}{c}\text { Financial Management. Strategy; Financial } \\
\text { Engineering; Practical Application of Finance } \\
\text { Theory }\end{array}$ & $\$ 32,000$ \\
\hline Kent State & $\begin{array}{l}\text { Derivatives, Finance Engineering, Finance } \\
\text { Management, }\end{array}$ & $\begin{array}{c}\$ 17,000 \text { in-state } \\
\$ 25,000 \text { out-of-state }\end{array}$ \\
\hline Penn State & $\begin{array}{c}\text { Debt/Equity Trading; Financial Information } \\
\text { Systems; etc. }\end{array}$ & \\
\hline St. Joseph's University & Practical Application for Finance Students & $\begin{array}{l}\text { Undergrad: } \$ 22,610 / \text { year } \\
\text { MBA: } \$ 1,800 / \text { course }\end{array}$ \\
\hline University of Virginia & Practical Application for Finance Students & $\begin{array}{c}\text { Undergrad: } \$ 4,600 \text { in-state; } \\
\$ 19,800 \text { out-of-state } \\
\text { Grad: } \$ 20,150 \text { in-state; } \$ 25,150 \text { out-of-state }\end{array}$ \\
\hline Baruch College & Practical Application for Finance Students & $\begin{array}{c}\text { Undergrad: \$170/credit in-state; \$360/credit } \\
\text { out-of-state; MBA: } \$ 330 / \text { credit in-state; } \\
\text { \$555/credit out-of-state }\end{array}$ \\
\hline $\begin{array}{l}\text { George Washington } \\
\text { University }\end{array}$ & Practical Application of Finance Theory & Undergrad: $\$ 41,000 /$ year \\
\hline Rutgers Business School & Practical Application for Finance Students & $\begin{array}{c}\$ 14,500 / \text { year in-state; } \\
\$ 20,484 / \text { year out-of-state } \\
\end{array}$ \\
\hline Oklahoma State University & Risk Management & $\begin{array}{c}\text { Grad: \$208/credit hr. in-state; } \$ 375 / \text { credit } \\
\text { hr. out-of-state }\end{array}$ \\
\hline Alaska Pacific University & Global Finance Applications & $\$ 450 /$ credit hr. \\
\hline $\begin{array}{l}\text { Ithaca College Center for } \\
\text { Trade and Analysis of } \\
\text { Financial Instruments } \\
\end{array}$ & Financial, Currency, and Commodity Markets & $\$ 696 /$ credit hr. \\
\hline Michigan State University & Financial Modeling, Valuation & $\begin{array}{c}\text { Undergrad: \$13,572/year in-state; } \$ 22,580 \\
\text { out-of-state; Grad: } \$ 15,460 / \text { year in-state; } \\
\$ 20,342 / \text { year out-of-state } \\
\end{array}$ \\
\hline University of Michigan & Practical Application for Finance Students & $\begin{array}{c}\text { Grad: \$42,932/year in-state; } \$ 47,932 / \text { year } \\
\text { out-of-state; Undergrad: Undergrad - } \\
\text { unavailable } \\
\end{array}$ \\
\hline University of Maryland & $\begin{array}{c}\text { Market Microstructure, Risk Management } \\
\text { Strategies, Derivatives Pricing, Financing and } \\
\text { Valuation } \\
\end{array}$ & $\begin{array}{c}\$ 750 / \text { credit hr. in-state; } \\
\$ 1,236 / \text { credit hr. out-of-state }\end{array}$ \\
\hline $\begin{array}{c}\text { William Paterson University } \\
\text { Christos M. Costakos } \\
\text { College of Business } \\
\end{array}$ & Asset Pricing Models, Option Models & $\begin{array}{c}\text { Undergrad: } \$ 6,400 / \text { year in-state; } \\
\$ 10,200 / \text { year out-of-state; Grad: } \$ 358 / \text { credit } \\
\text { hr. in-state; } \$ 535 / \text { credit hr. out-of-state }\end{array}$ \\
\hline University of Rhode Island & N/A & \\
\hline $\begin{array}{l}\text { University of Washington } \\
\text { Business }\end{array}$ & Practical Application for Finance Students & $\begin{array}{c}\text { Undergrad: } \$ 15,243 / \text { year in-state; } \\
\$ 26,339 / \text { year out-of-state; } \\
\text { Grad: N/A }\end{array}$ \\
\hline UT Austin & $\begin{array}{c}\text { Investments, Information Impact } \\
\text { Management, MBA Investment Fund, LLC, } \\
\text { Executive Education }\end{array}$ & $\begin{array}{l}\text { MBA: } \$ 27,635 / \text { year in-state; } \$ 41,795 \text { out- } \\
\quad \text { of-state; } \$ 42,441 \text { international }\end{array}$ \\
\hline Wake Forest University & $\begin{array}{c}\text { Finance Concentration: Investment Banking, } \\
\text { Corporate Finance, Financial Analysis, } \\
\text { Security Analysis/Asset Management }\end{array}$ & $\$ 26,500$ per year \\
\hline University of St. Thomas & Investment Fund Management & \\
\hline
\end{tabular}




\section{PURPOSE AND NEED}

The purpose of a trading room at a university is to provide a center for learning which facilitates the training of students as financial traders and increases awareness of financial markets, their workings, and their rules and regulations. The desire to have a trading room is also consistent with a business college's mission of 'excellence in teaching.'

A trading room provides business students - especially economics and finance majors or minors - with valuable real world experiences in an academic environment. By learning and understanding the microstructure of financial markets, students can better develop and implement trading strategies to fulfill the performance requirements of their clients when they graduate and accept positions in the industry. A mission of excellence in teaching is consistent with this type of experiential learning initiative.

Clearly, financial markets in the United States have undergone drastic changes in the last few decades. Until a few years ago, the dominant types of stock markets were floor-based like the NYSE. Since the establishment of the National Association of Securities Dealers Automated Quotation (the NASDAQ) system in the early 1970s, there has been a proliferation of automated trading systems, and, although floor-based trading may continue to exist for some time, it faces increasing competition from automated trading systems. In the last few years, the NASDAQ has overtaken the NYSE in both share and dollar volume transaction. ${ }^{3}$ In the derivatives markets, the International Securities Markets achieved a sixteen percent share of US equity option trading (Harris (2003)) within eighteen months of their 2000 launch. Thus, the importance of automated trading systems cannot be over-emphasized. Even the NYSE, which to date has resisted full automation, has adopted some form of electronic trading.

Automated trading systems perform better than floor-based trading systems in the following areas: speed, accessibility, convenience, and costs, including set-up, labor and communications. Automated systems are also superior at providing audit trails. However, in spite of their apparent advantages, most floor-based exchanges in the United States, such as the NYSE and the Chicago Board of Trade (the CBOT), have resisted using automated trading mechanisms. In addition, some floor-trading supporters have justified their resistance by pointing to failed attempts to establish automated trading systems, such as those at the Arizona Stock Exchange and the Optimark system. ${ }^{4}$

Globally, however, there has been some spectacular success for automated trading systems. The Paris Bourse established an automated trading system in 1989 and since then much of the trading on French stocks has migrated from London to Paris. The electronic German DTB futures exchange also succeeded in moving trading in German Tbond futures from the London International Financial Futures Exchange (the LIFFE) to itself.

Proponents of floor-based systems suggest that their tremendous success is largely due to their floor-based market structure. However, as automated trading structures are being adopted, and increasingly providing the same, or better, level of service as floor-based trading systems, the resistance to automated trading systems has been on the decline, and automated trading structures are expected to become more prevalent in the United States of America.

Keeping this trend in perspective, a number of universities in the United States have established facilities that provide "an accurate simulation of a live trading floor." The term "trading room" or "trading floor" is usually used to refer to such a facility. It can also be observed from Table 1 that university trading rooms, such as those at Oklahoma State, Michigan State and Penn State, among others, have primarily focused on the equity market. Only a few have focused on financial derivatives, commodities, or commodity derivatives. Kent State University places its primary focus on financial derivatives, while Ithaca College includes commodities as one of its areas of focus. Hence, we believe that some of the soon-to-be-created trading rooms should focus on commodity and commodity derivatives. Such trading rooms would join the few in the nation which have an integrated commodity and commodity derivative

\footnotetext{
${ }^{3}$ Source: NASD Economic Research, as of June 6, 2000.

${ }^{4}$ Using a CRAY supercomputer, Optimark provided a highly innovative trading system. Traders could create "profiles" for their orders. In spite of the initial excitement, it did not generate much order flow. Accumulated losses through September 2001 were 406 million dollars.
} 
focus. A list of commodity and commodity derivative exchanges with their websites and addresses is included in Table 2 .

One issue of concern, if a university decides to pursue the commodity and commodity derivative route, however, is that not all students who want to undergo training as a financial trader would be interested in commodities and commodity derivatives trading. One strategy to accommodate this fact would be to have the trading room linked to an equity exchange, which could be either the NASDAQ or the NYSE, or both, depending on the cost of linking to these exchanges. The trading floor would then allow for trading with equities, which are the most popular financial assets in the United States.

Indeed, a trading room that incorporates trading in equities, commodities, and commodity derivatives, with an integrated curriculum, would provide an opportunity for students that perhaps no other program or university currently provides in the United States. Moreover, given the expected need for finance professionals who would be skilled enough for trading in financial assets, and the uniqueness of such a trading room program, investing in it would be a worthwhile decision for any university.

Table 2: Commodity Exchanges, Products, and Home Page

\begin{tabular}{|c|c|c|}
\hline Name & Commodity Products & Home Page \\
\hline $\begin{array}{l}\text { Chicago Mercantile } \\
\text { Exchange }\end{array}$ & $\begin{array}{l}\text { Live Cattle, Feeder Cattle, Lean Hogs, Pork Bellies, } \\
\text { Lumber, Dairy. }\end{array}$ & $\underline{\text { http://www.cme.com/ }}$ \\
\hline $\begin{array}{l}\text { Chicago Board of } \\
\text { Trade }\end{array}$ & $\begin{array}{l}\text { Live Cattle, Feeder Cattle, Lean Hogs, Pork Bellies, } \\
\text { Lumber, Currencies, S \& P 500, Mini S\&P 500, } \\
\text { Mini NASDAQ, Mid Cap 400, Nikkei 225, } \\
\text { Treasury Bills. }\end{array}$ & http://www.cbot.com/ \\
\hline $\begin{array}{l}\text { New York } \\
\text { Mercantile } \\
\text { Exchange }\end{array}$ & $\begin{array}{l}\text { Unleaded Gas, Heating Oil, Natural Gas, Crude Oil, } \\
\text { Platinum, Palladium, Silver, Gold, Copper. }\end{array}$ & http://www.nymex.com \\
\hline $\begin{array}{l}\text { New York Board of } \\
\text { Trade }\end{array}$ & $\begin{array}{l}\text { Coffee, Sugar, Cocoa, Cotton, Orange Juice, } \\
\text { NYFE, FINEX, SPCI, CRB. }\end{array}$ & http://www.nybot.com \\
\hline $\begin{array}{l}\text { Kansas City Board } \\
\text { of Trade }\end{array}$ & KC Value Line, KC Mini Value Line, KC Wheat. & $\underline{\text { http://www.kcbt.com/products.html }}$ \\
\hline $\begin{array}{l}\text { Minneapolis Grain } \\
\text { Exchange }\end{array}$ & $\begin{array}{l}\text { Hard Red Spring Wheat, Hard Winter Wheat Index } \\
\text { (HWI), National Corn Index (NCI) and National } \\
\text { Soybean Index (NSI). }\end{array}$ & $\underline{\text { http://www.mgex.com/index.cfm }}$ \\
\hline
\end{tabular}

\section{TYPICAL TRADING ROOM}

The trading room in the academic environment differs from university to university and may reflect a university's desire to have a trading room that closely resembles those found in the real world. ${ }^{5}$

Basically, the layout of a trading room includes a large room surrounded by a number of small rooms. The large room may serve as the instructional room and the small rooms may have different purposes. One of the small rooms, for instance, may serve as a conference room, while another may house the network and other equipment. Another small room may have additional computers which can be used when the main room is in use by a class. Another small room may be useful as a faculty room or control room.

\footnotetext{
${ }^{5}$ Examples of trading room facilities may be provided upon request.
} 
In general, the instructional room has the centrally located teaching station and the trading stations for students. It also houses the audio-visual equipment needed for instructional purposes and displays. In the instructional room at Penn State, for instance, two 64-block ticker boards are used to display data from Bloomberg, Reuters, and the data feed from the exchanges. Streaming tickers line the back and side of the room and are used to display additional data. The two projector screens along with three plasma screens can display instructional material from the professor's computer, Bloomberg, VCR, Reuters, document camera, or any other source in the room. In addition to having a laptop and other peripherals, the room is also equipped with video conferencing capabilities.

The number of terminals in the trading room depends on the desired class size, glitz and ambience. A financial trading room can provide a sense of technological sophistication and, if appropriately located in the business school, it can significantly affect the ambience of the entire school.

The two integral parts of the trading room are the data feed and the computer technology used for the data feed. The data feed consists of data from exchanges and from database providers such as Bloomberg or Reuters. The computer technology component consists of hardware and software. Hardware includes both the PCs and the computer network. Due to the volume of data that is processed, the trading room needs to have top of the line PCs as well as networks. As part of the hardware, appropriate satellite connectivity may have to be maintained depending upon how the data feed from the exchanges are obtained.

A number of software packages are required. One of the most important is the Financial Trading System. This system simulates trading without the real transaction being carried out. With this system, if a student based in trading room decides to adopt a particular position, the trading system carries out that transaction with live data coming in from the exchanges, but information about the transaction is not sent back to the exchanges. The student can experience feeling part of a real transaction without the transaction being real. Other software packages that may be needed in a trading room include Matlab and SAS. Both of these are statistical packages and are very popular in the finance service industry.

\section{CRITICAL ISSUES: CURRICULUM AND PERSONNEL}

Although several universities have trading program facilities, not all have been able to run and utilize them successfully. Two main critical factors determine the success of the trading-room training program: (a) curriculum and (b) personnel.

\section{Curriculum}

A list of Applied Economics and/or Finance courses offered in our hypothetical university, included in Table 3 , is used herein for the purpose of example and discussion. As indicated, it comprises a total of sixteen courses. Of these sixteen, only four can make extensive use of the trading floor, but these would require adjustments to their way of teaching.

These courses are named Applied Economics and Financial Modeling, Speculative Markets, Principles of Investments, and Security Analysis and Portfolio Management. For example, Applied Economics and Financial Modeling examines statistical and econometric models for forecasting. However, to design and implement a particular model in a particular financial market, a person has to understand the microstructure of that financial market. The course Speculative Markets provides knowledge about the financial derivative markets. However, the amount of course material that needs to be covered in class is such that students would be ready to use the trading room only after they have completed the course. The courses Principles of Investments and Security Analysis and Portfolio Management have the same related issues, and Fundamentals of Finance and Managerial Economics I/Business Finance are introductory courses, for which the trading room can only be utilized to show some aspects of financial trading to the students. 
Table 3: List of Existing Applied Economics/Finance Courses at Hypothetical University

\begin{tabular}{|c|c|}
\hline Course & Description \\
\hline $\begin{array}{c}\text { Fundamentals of } \\
\text { Finance }\end{array}$ & $\begin{array}{l}\text { Explores the financial system and the changing environment within which the financial manager } \\
\text { works and to which he/she must continually adjust. This is an introductory course in finance } \\
\text { reflecting mainly the needs of non-business majors. }\end{array}$ \\
\hline $\begin{array}{l}\text { Managerial Economics } \\
\text { I/ Business Finance }\end{array}$ & $\begin{array}{l}\text { Examines the methods utilized by corporations in securing and utilizing capital, capital } \\
\text { structure, and characteristics of alternative forms of capital. }\end{array}$ \\
\hline $\begin{array}{l}\text { Principles of } \\
\text { Investments }\end{array}$ & $\begin{array}{l}\text { Teaches the essential qualities of good investments, exchanges, and methods of trading stocks } \\
\text { and bonds. }\end{array}$ \\
\hline Real Estate Principles & $\begin{array}{l}\text { An introduction to the legal, economic, and financial environment of real estate transactions. } \\
\text { Topics include property rights, buying, financing, and selling of real estate. }\end{array}$ \\
\hline Real Estate Finance & $\begin{array}{l}\text { Students learn of the legal environment of the financing of real estate, availability and sources of } \\
\text { mortgage funds, affordability and decisions to borrow on owner-occupied residences, and } \\
\text { analysis for financing income producing properties. }\end{array}$ \\
\hline Real Estate Valuation & $\begin{array}{l}\text { In depth coverage of the traditional approaches to real estate appraisal, emphasizing the } \\
\text { discounted cash flow techniques for income properties. Discusses techniques for analyzing the } \\
\text { real estate market and forecasting cash flows }\end{array}$ \\
\hline $\begin{array}{l}\text { Managerial Economics } \\
\text { II/ Financial } \\
\text { Management }\end{array}$ & $\begin{array}{l}\text { A comprehensive terminal course that gives consideration to developing sound financial policies } \\
\text { in the firm. The course will use cases to develop concepts in such areas as capital budgeting and } \\
\text { capital structure. }\end{array}$ \\
\hline $\begin{array}{l}\text { International } \\
\text { Economics and } \\
\text { Financial Management }\end{array}$ & $\begin{array}{l}\text { This course deals with theoretical and practical issues of corporate financial management in an } \\
\text { international environment. Emphasis is placed on decision making by multinational firms in } \\
\text { capital budgeting, working capital management, and the procurement of funds in international } \\
\text { markets. }\end{array}$ \\
\hline $\begin{array}{l}\text { Security Analysis and } \\
\text { Portfolio Management }\end{array}$ & $\begin{array}{l}\text { An examination of the precepts underlying the valuation of securities and an analytical handling } \\
\text { of the various techniques of securities analysis. }\end{array}$ \\
\hline Speculative Markets & $\begin{array}{l}\text { This course examines both practical and theoretical aspects of financial futures and } \\
\text { options markets. Included will be discussions of theoretical models, hedging strategies, } \\
\text { and the practical uses of these securities. }\end{array}$ \\
\hline $\begin{array}{l}\text { Applied Economics } \\
\text { and Financial } \\
\text { Modeling }\end{array}$ & $\begin{array}{l}\text { In this course, models for asset allocation, security selection, portfolio hedging, stocks } \\
\text { valuation, bond valuation, and derivative pricing are discussed. Simple statistical and } \\
\text { econometric methods of forecasting may be examined. The course is an elective } \\
\text { intended for students who are in the finance track (minors and majors). }\end{array}$ \\
\hline Internship & $\begin{array}{l}\text { Students work during the summer in a program approved by the employer and faculty. } \\
\text { Positions and credit hours must be approved prior to registration. A written report is } \\
\text { required of the student and a written evaluation by the employer must be made to the } \\
\text { supervising university instructor. }\end{array}$ \\
\hline $\begin{array}{l}\text { Financial } \\
\text { Institutions }\end{array}$ & $\begin{array}{l}\text { This course focuses on the institutional structure of the financial system. Surveys both } \\
\text { the public and private sectors of our money and credit economy. Emphasis placed on } \\
\text { understanding the impact of the commercial banking system, financial intermediaries, } \\
\text { and public finance needs upon the conduct of business finance. }\end{array}$ \\
\hline $\begin{array}{l}\text { Commercial Bank } \\
\text { Management }\end{array}$ & $\begin{array}{l}\text { Investigates the procedures used for appraisal of credit risks and selection of } \\
\text { investments. Attention is given to the influence of the regulatory environment and the } \\
\text { problem of shifts in deposit liabilities. }\end{array}$ \\
\hline $\begin{array}{l}\text { Short-Term } \\
\text { Financial } \\
\text { Management }\end{array}$ & $\begin{array}{l}\text { The activities and principles of short-term financial management are developed and } \\
\text { analyzed. The treasury function and its relationship to cash management, credit } \\
\text { management, and money market investments is studied. Practices in the field of } \\
\text { working capital management are also described and evaluated. }\end{array}$ \\
\hline Seminar & $\begin{array}{l}\text { Investigation of significant current topics in practice and theory in the areas of } \\
\text { corporate financial management, money markets, investments, commercial banking, } \\
\text { and financial institutions. }\end{array}$ \\
\hline
\end{tabular}

Therefore, new courses need to be introduced in order to justify making an investment in a trading floor. Table 4 provides a list of eleven courses that can make use of the trading floor. Of these eleven courses, our 
hypothetical university already offers six and would need to introduce five new courses. The five new courses are Market Microstructure, Quantitative Methods in Economics and Finance, Negotiating Financial Transactions, Legal and Ethical Issues and Seminar: Advanced Project Modeling. Exhibit 4 also provides brief descriptions of the five new courses.

Table 4: List of Courses Needed For Trading Room-Related Programs

\begin{tabular}{|c|c|}
\hline Course & $\begin{array}{ll}\text { Description } \\
\end{array}$ \\
\hline $\begin{array}{l}\text { Fundamentals of } \\
\text { Finance* }\end{array}$ & $\begin{array}{l}\text { Explores the financial system and the changing environment within which the financial } \\
\text { manager works and to which he/she must continually adjust. This is an introductory course in } \\
\text { finance reflecting mainly the needs of non-business majors. }\end{array}$ \\
\hline $\begin{array}{c}\text { Managerial Economics I/ } \\
\text { Business Finance* }\end{array}$ & $\begin{array}{l}\text { Examines the methods utilized by corporations in securing and utilizing capital, capital } \\
\text { structure, and characteristics of alternative forms of capital. }\end{array}$ \\
\hline Principles of Investments* & $\begin{array}{l}\text { Teaches the essential qualities of good investments, the exchanges, and methods of trading } \\
\text { stocks and bonds. Needs to incorporate Financial Statement Analysis. This course will } \\
\text { introduce fundamental concepts and techniques of common stock valuation. Analytical and } \\
\text { judgmental skills are developed, in order to improve decision-making capacity in purchasing } \\
\text { common stock. The theory covered in this course is supported by trading room activities using } \\
\text { Bloomberg. }\end{array}$ \\
\hline Speculative Markets* & $\begin{array}{l}\text { This course examines both practical and theoretical aspects of financial futures and options } \\
\text { markets. Included will be discussions of theoretical models, hedging strategies, and the } \\
\text { practical uses of these securities. }\end{array}$ \\
\hline $\begin{array}{l}\text { Security Analysis and } \\
\text { Portfolio Management* }\end{array}$ & $\begin{array}{l}\text { An examination of the precepts underlying the valuation of securities and an analytical } \\
\text { handling of the various techniques of securities analysis. }\end{array}$ \\
\hline $\begin{array}{l}\text { Applied Economics and } \\
\text { Financial Modeling* }\end{array}$ & $\begin{array}{l}\text { In this course, models for asset allocation, security selection, portfolio hedging, stocks } \\
\text { valuation, bond valuation, and derivative pricing are discussed. Simple statistical and } \\
\text { econometric methods of forecasting may be examined. The course is an elective intended for } \\
\text { students who are in the finance track (minors and majors). }\end{array}$ \\
\hline Market Microstructure & $\begin{array}{l}\text { This course provides students with an understanding of how financial markets work, and how } \\
\text { government and exchanges regulate them. Students will gain an understanding of how prices } \\
\text { reflect information about fundamental values, what affects market liquidity, and how to } \\
\text { design trading strategies to exploit market mispricing. }\end{array}$ \\
\hline $\begin{array}{l}\text { Quantitative Methods in } \\
\text { Economics and Finance }\end{array}$ & $\begin{array}{l}\text { In this course, students are introduced to differential calculus. Optimization and simulations } \\
\text { are also addressed using Matlab and Crystal Ball. Pricing models are derived and } \\
\text { implemented. Students gain hands-on experience in about time series models like ARIMA, } \\
\text { GARCH, unit roots and co-integration, and vector autoregressive models. }\end{array}$ \\
\hline $\begin{array}{l}\text { Negotiating Financial } \\
\text { Transactions }\end{array}$ & $\begin{array}{l}\text { This course introduces students to the daily activities of a real trading room: the use of trading } \\
\text { and financial information platforms such as Reuters and Bloomberg, the analysis of the } \\
\text { principal markets (equity, FX, Bond, and Commodity), and the role of the different market } \\
\text { participants. }\end{array}$ \\
\hline Legal and Ethical Issues & $\begin{array}{l}\text { This course provides students with an understanding of the legal, regulatory and compliance } \\
\text { aspects of exchanges. The microstructures of exchanges are greatly influenced by the rules } \\
\text { and regulations that govern them. An understanding of these rules and regulations provides an } \\
\text { understanding of do's and don'ts, which are very important while devising trading strategies. }\end{array}$ \\
\hline $\begin{array}{l}\text { Seminar: Advanced } \\
\text { Modeling Project }\end{array}$ & $\begin{array}{l}\text { The purpose of these projects is application of theoretical models learned in various courses. } \\
\text { The main objective of this course is to train students to develop trading strategies that can be } \\
\text { implemented within constraints set by the rules and regulation of exchanges. The faculty's } \\
\text { role is to be a facilitator, and as such faculty input will be minimal and focused on the quality } \\
\text { of work done by the student. Students will undertake a variety of individual and small-group } \\
\text { projects. Students must complete all other courses before signing up for this course. }\end{array}$ \\
\hline
\end{tabular}

* Indicates courses already offered by our hypothetical university. 


\section{Personnel}

A critical factor for the successful usage of the trading room is personnel - teachers, support staff, and "champions" for the trading room. The quality of instruction in the trading room depends on the interest and the desire of the faculty to innovate and use the resources. At various institutions, experience shows that not all faculty members are interested in teaching courses that use the trading room. Moreover, some faculty members may be reluctant to spend time learning new software packages, or financial databases. This issue is of concern, even if the entire applied economics and finance faculty were interested in using the trading room.

As we previously mentioned for our hypothetical college, at least five new courses need to be introduced in order to fully utilize the trading room. Assuming the applied economics/finance program at our hypothetical university may have five faculty members, each with a course load of three hours per semester, introducing and offering five new courses may put too much strain on those current faculty members. Thus, new faculty may have to be recruited or part-time faculty may be required for lower-level classes to free up time for the tenure-line faculty to teach advanced classes. Unfortunately, the quality of instruction in the courses taught by the part-time instructors may suffer. As a result, tenure-line faculty may have to review the course material covered in the lower-level courses for quality control purposes, because the part-time instructors may not be subjecting students to the level of rigor that is required by the program.

Faculty consideration becomes an even more critical issue if a program is not built around the trading room. If courses designed to use the trading room are not required, the use of the trading room would be dependent upon the interest of the faculty. As gaining new knowledge and skills would require faculty to take time away from their already existing research, teaching, or service commitments, faculty members may not have any incentive to retrain themselves. If faculty interest and training are not properly addressed, the investment in a trading room may be unjustified.

Although not as critical as faculty interest and training, support staff may still be an important consideration. Support staff is needed to help students learn how to program statistical packages. Economics and finance teachers are responsible for teaching applied economics concepts and showing students how to use and program statistical packages. However, assuming a class size of twenty-five students, for instance, faculty members may not have enough time to provide sufficient attention to each student. Additional support staff, such as graduate students working as teaching assistants, would be needed.

Another major factor that has determined the success or failure of trading rooms at a few institutions is the "champion" of the trading room. The champion, who could be a department chair, program coordinator or a faculty member, takes care of a variety of issues that arise just by having the trading room. The role of the champion is that of a facilitator. The champion is the person responsible for liaising with the contact person at the exchange and having problems fixed. The champion may also have to interact with firms and companies that will provide internship for students enrolled in the trading room program. Interacting with alumni may be another responsibility of the champion of the trading room. Another role is interaction with university officials for administrative purposes. The champion has been a critical success factor for a number of institutions and may have the same sort of impact for a new trading room program.

\section{SUMMARY AND CONCLUSIONS}

If carefully organized and managed, a trading room provides many benefits that far outweigh the financial costs and concerns outlined herein. As previously mentioned, the two major expenses associated with a trading room are (1) the initial set up cost and (2) the on-going operating expenses. Although a budget for a trading room can vary, upon request the authors may provide one for a hypothetical university. As to the benefits related to a trading room, they are as follows: 


\section{(1) Reputation Capital}

The trading room with all its cutting edge technology - hardware, software, and real time data feed - will add to the reputation capital of any institution (Alexander et al. (2001)). The upscale equipment will bring a degree of sophistication that will enhance the reputation of the school or college. The trading room will also add to the ambience and learning environment. The excitement of the market, the electronic displays, and the high-tech nature of the trading room will communicate numerous positive attributes of the institution.

\section{(2) Student Placements}

Graduates of the trading room program will be at a competitive advantage, as they will have been trained on equipment which is very similar to that used when they acquire positions within the industry. Employers will find these graduates economically attractive because they will not have to spend significant time and money training them. Students can anticipate more avenues of employment and higher salaries after graduation, among other rewards.

\section{(3) Student Enrollment}

The trading floor may help an institution attract new students both within and outside the state, since the trading room will provide students with an opportunity to enroll in a high quality program.

\section{(4) Faculty Recruiting}

The trading room may also make an institution more attractive to highly qualified faculty, when attempts are made to recruit new faculty members.

\section{(5) Faculty Research}

The type of data available in the trading room will be useful not only for the Economics and Finance faculty but also for faculty in Accounting, Statistics, and MIS. Real-time availability of reliable data will reduce the time spent on collecting and validating data, which can impact positively upon research productivity. Greater research output also enhances the reputation of an institution and helps maintain its accreditation.

\section{(6) Alumni Relations}

The trading room will improve the institution's relationship with its alumni, both existing and new ones, as students graduate. Alumni will use the institution's trading room initiatives to enhance its reputation both within the state and across the nation, adding to the prestige of the diploma earned from the university. This also places the university in a better position to solicitate donations and endowments from its alumni.

\section{(7) Industry Relationship}

The trading floor will also strengthen the university's relationship with the industry, especially with the exchanges to which our trading room will be linked. The exchanges will have an interest in the success of the program, especially considering that just a few universities provide training about products traded on the exchanges. Other industry participants will also have an interest because the university in question will be among the few from which they may recruit overall trained and qualified individuals.

\section{(8) Non-traditional Students}

The trading room will also help the university attract non-traditional students, i.e., students who already have jobs but who want to learn advanced trading to further their careers, or who are sent to university by their firms to upgrade their knowledge and skills. This would be especially attractive to professionals in or around major cities. As well, universities that are not in large, populated cities can have a trading room center so that non-traditional students 
will have the opportunity to undergo advanced training without having to move away from where they work and live. This could also be an additional source of revenue, which can be used to maintain and improve the trading room facilities.

As to non-direct financial concerns related to a trading room project they include:

\section{(1) Improper Use}

The biggest concern about the trading room is its improper and incomplete utilization. Examining the experience of a few universities, trading rooms often have a tendency to become glorified computer labs. The cost of creating and maintaining a trading room does not justify its use as a computer lab.

\section{(2) Curriculum Issues}

One major factor that influences the success of a trading room program is curriculum. Institutions that do not have a curriculum structure that makes full use of the trading room tend to not be able to prevent the trading room from degenerating into a glorified computer lab. Changing curriculum, however, is neither easy nor quick, as bureaucratic bodies at the college, university and sometimes even at the state level need to be consulted.

\section{(3) Faculty Concerns}

The faculty concerns could be of three types - quality, interest and number. The quality of faculty in most institutions is not a major issue, but should one or more faculty member choose to pursue a career elsewhere, it may become an area of concern. Faculty interest and numbers can also be areas of concern. Not all faculty members may be interested in undergoing the rigorous training that is needed to bring the real world into the trading room at a university. Moreover, if we assume that all economics and finance faculty are interested in the trading room, the problem of the number of faculty still remains a concern. Even after a revision of the curriculum, some of the current courses would still have to be taught. New faculty may have to be hired, and that could become a major issue. Part time faculty could teach some of the courses, but the quality of instruction could deteriorate.

\section{(4) Student Placement and Enrollment}

The finance service industry is highly cyclical. Recruitment by industries is influenced by how the economy performs. Difficult economic times may affect student placements; hence the attractiveness of the program may decrease, resulting in a decline in student enrollment.

\section{REFERENCES}

1. Alexander, John, C. C. Heck, and R. B. McElreath, 2001, A Guide to Building a University Trading Room, Financial Services Review, v10, pp 209-220.

2. Harris, L., 2003, Trading and Exchanges: Market Microstructure for Practitioners, Oxford University Press, p 543.

3. Kolb, David, Experiential Learning, 1984, Englewood Cliffs: Prentice Hall.

\section{ACKNOWLEDGEMENTS}

The authors acknowledge the support for this project from NETWORKS. The authors would like to thank Dr. Eric Girard of Siena College, Dr. Carl Luft of DePaul University and Mike Persico, President of Tekom Inc., for valuable insights. Alex Savitchev, graduate assistant at Indiana State University, College of Business, for the academic year 2002-03, also provided valuable contributions which we acknowledge with gratitude. 